\title{
BIOLOGICAL PERFORMANCE AND ECONOMIC INDICATORS OF FATTENED BALADI BULLOCKS UNDER TWO FATTENING SYSTEMS
}

\author{
Amal K. El-Asheeri, A. S. Sami and M. A. Radwan \\ Animal Production Department, Faculty of Agriculture, Cairo University, Giza, \\ Egypt
}

\section{SUMMARY}

This study aimed at comparing between two fattening systems considering feeding type as a fixed effect. Ten Baladi bullocks were divided into two similar groups $(G)$ with an average body weight (BW) of 243 and $247 \mathrm{~kg}$ for Gland G2, respectively. Bullocks of G1 were fed on 100\% concentrate feed mixture (CFM), while in G2 75 $\%$ of CFM was replaced by maize silage. Animals were kept tied, fed individually and offered water thrice daily. Growth, carcass and economic traits of the two groups were studied. Animals were weighed bi-weekly to characterize growth features up to reaching the target weight of $430 \mathrm{~kg}$. By the end of the experiment bullocks were slaughtered to estimate carcass traits. Total variable costs, total income, gross margin, benefit/ cost ratio and cost of $1 \mathrm{~kg}$ gain were calculated.

Growth curve of $G 1$ and $G 2$ was consistent up to the $10^{\text {th }}$ wh of fattening period, thereafter, $B W$ tended to be higher in G1. Fattening period (252.0 \pm 6.7 day) of G2 increased $(P<0.001)$ by $25.1 \%$ more than $G 1$ (201.4 \pm 6.7 day), while ADG of G1 was higher $(0.96 \pm 0.03 \mathrm{~kg}, P<0.001)$ than of $G 2(0.72 \pm 0.03 \mathrm{~kg})$. Feed conversion was better $(P<0.01)$ in $G 1(8.2 \pm 0.4 \mathrm{~kg} / 1 \mathrm{~kg}$ gain) than in $\mathrm{G} 2(9.9 \pm 0.4 \mathrm{~kg} / 1 \mathrm{~kg}$ gain). No difference was observed concerning carcass traits of the two studied groups.

Total variable cost of $G 1$ was higher $(P<0.02)$ than of $G 2$ by $7.1 \%$, meanwhile no difference was found in total income. Benefit / cost ratio was higher $(P<0.04)$ in $G 2(1.16 \pm 0.4)$ than in $G 1(1.1 \pm 0.4)$. Also, lower $(P<0.02)$ cost of producing $1 \mathrm{~kg}$ gained weight in $G 2$ (L.E $9.3 \pm 0.4$ ) was recorded compared to G1 (L.E. $11.0 \pm 0.4)$.

In conclusion replacing concentrate feed mixture up to $75 \%$ with maize silage had a positive impact on benefit/cost ratio of Baladi bullocks under Egyptian condition.

Keywords: Baladi bullocks, feeding, growth, carcass, and economic indicators

\section{INTRODUCTION}

In Egypt, feedlot system represents the main source of fattened Baladi or buffalo calves. This system relies on feeding calves on concentrate mixture, which represents the major variable of running costs (86 to $93 \%$ ) (Alsheikh et al., 2004 and ElAsheeri, 2008). Minimizing the cost of input under this system is a way to keep feedlots profitable, under the global increase in cereal price.

Issued by The Egyptian Society of Animal Production 
Average daily gain (ADG) is an indicator of genetic makeup and calf's capacity of feed conversion. Many trials conducted to estimate ADG of Baladi calves reported a wide range of 600 - $1228 \mathrm{~g}$ (Askar and Ragab, 1958; Kamer et al., 1961; Galal et al., 1973; Omar et al., 1993; Sadek et al., 1993, El-Bedawy et al.,1996, Alsheikh et al., 2004, El-Bedawy et al.,2004 and El-Asheeri, 2008). ADG is reported to be a determinant factor of farm profitability (Amal El-Asheeri, 2008), which comes in consensus with the finding of Nigm et al. (1984) reporting that feed conversion is the main factor influencing farm profitability.

Limited studies aimed at manipulating feeding types to replace concentrate feed ixture. Many trials (Mader et al., 1991; Sami et al., 2004; Kirkland et al., 2005; and Cozzi et al., 2005) fed beef breeds on corn silage only and reported ADG between 0.92 and $1.4 \mathrm{~kg}$. Young et al. (1978); Karadjoli et al. (1983) and Rossi and Loerch (2001) replaced part of concentrate feed mixture with maize silage $(25-85 \%)$. They reported close ADG between studied groups, however calves fed on maize silage spent longer fattening period to reach the target weight. El-Bedawy et al. (1996 \& 2004) on their study on Baladi calves added protected fat to fattening rations to increase energy intake. The authors reported no difference in ADG between the control and treated groups (1024-1097 g). Feeding on maize silage is recently adopted by animal producers to minimize feeding costs. Studies of Wand \& McEwen (2003) and Sewell \& Wheaton (1993) reported good nutritive value of maize silage however. No studies are available to determine the economic return of feeding on maize silage on growth performance and benefit / cost ratio under Egyptian conditions.

The present study was designed to compare between two feeding types for fattening Baladi bullocks.

\section{MATERIALS AND METHODS}

\section{Animals and management}

The present study was carried out during the period from April to December 2007 in the Fattening Research Unit, Agriculture Experimental Station, Faculty of Agriculture, Cairo University, Giza, Egypt. A total of 10 Baladi (local) bullocks (Bos indicus) were purchased from the local market. Animals were diagnosed as free from diseases and treated upon purchasing against internal and external parasites. Animals were housed in a semi open yard and kept tied throughout the experimental period. Animals were watered thrice daily, while feed allowances based on NRC (1996) requirement were offered twice daily.

Animals were divided into two similar groups $(n=5)$ and initial body weight $(B W)$ (Table 2). Feeding requirements of the $1^{\text {st }}$ group (G1) were covered by concentrate mixture and rice straw, while in the $2^{\text {nd }}$ one $(\mathrm{G} 2) 75 \%$ of the concentrate mixture requirement was replaced by maize silage. Feed stuffs were chemically analyzed according to A.O.A.C. (2000) (Table 1). Feed intake was estimated daily and BW was recorded bi-weekly throughout the experimental period that ended up when animals reached $\mathrm{BW}$ of $430 \mathrm{~kg}$.

At the end of the experiment calves were weighed (FBW) and slaughtered, according the Halal rules, after fasting period of $16 \mathrm{hrs}$. After bleeding, calves were skinned, eviscerated and sectioned down through the vertebral column into two halves. Rib cut $\left(9,10\right.$ and $11^{\text {th }}$ ribs) was separated from the left side and area $\left(\mathrm{cm}^{2}\right)$ of 
the fresh section of Longissimus dorsi ( $L$ dorsi) $\left(9^{\text {th }}\right.$ rib) was estimated by a planimeter. Rib cut was weighed and after chilling at $4^{\circ} \mathrm{C}$ for $24 \mathrm{~h}$ it was dissected into bone, lean and fat. After deboning the carcass, boneless meat were weighed.

Table 1. Chemical composition of feed stuffs

\begin{tabular}{lccc}
\hline Items & $\begin{array}{c}\text { Concentrate } \\
\text { mixture }\end{array}$ & Maize silage & Rice straw \\
\hline Dry matter (\%) & 92 & 34 & 90 \\
Crude protein (\%) & 15 & 8.0 & 3.5 \\
Ether extract (\%) & 4.4 & 6.1 & 1.0 \\
Crude fiber (\%) & 9.2 & 16.0 & 40 \\
NFE (\%) & 62.1 & 60.9 & 50 \\
Ash (\%) & 9.3 & 9 & 6.0 \\
\hline
\end{tabular}

Table 2. Growth performance (LSM \pm S.E) of Baladi bullocks fattened on $\mathbf{1 0 0 \%}$ concentrate feed mixture (G1) and on $25 \%$ concentrates feed mixture plus $75 \%$ maize silage (G2)

\begin{tabular}{lcccc}
\multicolumn{1}{c}{ Item } & G1 & G2 & \pm S.E & P value \\
\hline Number of animals & 5 & 5 & & \\
Initial body weight (kg) & 243 & 247 & 4.2 & 0.5 \\
Final body weight (kg) & 437.4 & 428.8 & 3.9 & 0.2 \\
Average daily gain (kg) & 0.96 & 0.72 & 0.03 & 0.001 \\
Fattening period (day) & 201.4 & 252 & 6.7 & 0.001 \\
Dry matter intake (kg/day) & 7.9 & 7.1 & 0.1 & 0.0004 \\
Feed conversion (kg DMI/ kg gain) & 8.2 & 9.9 & 0.4 & 0.01 \\
\hline
\end{tabular}

\section{Measurements}

1. Biological and carcass traits

In addition to the biological parameters (growth curve; ADG and feed conversion); physical components of the rib cut (bone $\%$, fat $\%$ and lean $\%$ ), dressing $\%$ and boneless meat $\%$ were calculated as carcass measurements.

\section{Economic indicators}

- Running cost (L.E)

- Total variable cost (L.E)

- Total outputs (L.E)

- Benefit /cost ratio (L.E)

- Gross margin (L.E)

- Cost of producing $1 \mathrm{~kg}$ gain (L.E) = Total running cost / total gain (Omar et al., 1993)

- Dressing \%

- Boneless meat \%

$=$ carcass weight $/$ FBW multiplied by 100

$=$ Costs of feeding, labor and veterinary care

$=$ Running cost + Purchasing price of calves

$=$ Selling price + manure price

$=$ Total income $/$ Total variable cost

$=$ Total outputs - Total variable cost

$=$ Meat weight $/$ FBW multiplied by 100

Technical Coefficients

Prices of year $\mathbf{2 0 0 7}$ were used as follows:

- Concentrate feed mixture

- Maize silage

- Rice straw

$=$ L.E $1475 /$ ton

$=$ L.E $200 /$ ton

$=$ L.E $110 /$ ton 
- Purchase price

- Selling price

- Manure price

- Veterinary care cost

- Casual labor cost
$=$ L.E $14.5 / \mathrm{kg}$ live body weight

= L.E $13.75 / \mathrm{kg}$ live body weight

$=\mathrm{L} . \mathrm{E} 15.0 / \mathrm{m} 3$

$=$ L.E $30 /$ animal

$=$ LE $20 / 50$ head $/$ day

\section{Statistical analysis}

Data were statistically analyzed according to SAS (2001). Data in percentages were transformed to the arcsine square-root in an effort to normalize the error analysis, using the following models:

$\mathrm{Y}_{\mathrm{ij}}=\mu+\mathrm{T}_{\mathrm{i}}+\mathrm{e}_{\mathrm{ij}}$

where

$\mathrm{Y}_{\mathrm{ij}}=$ the measured trait

$\mu=$ the overall mean

$\mathrm{Ti}=$ effect of feeding types $(\mathrm{T}=1,2 ; 1=$ fed on $100 \%$ concentrate feed mixture and $2=$ fed on $25 \%$ concentrate feed mixture plus $75 \%$ maize silage)

$\mathrm{e}_{\mathrm{ij}}=$ random error

\section{RESULTS AND DISCUSSION}

\section{Growth performance and related aspects}

The obtained results indicated that up to the $10^{\text {th }}$ week of fattening period, there was no difference between G1 and G2 in their growth curves. With the beginning of the $12^{\text {th }}$ week body weight of G1 tended to be higher and the difference between the two groups increased with time. Low ADG of G2 increased the fattening period required to reach the target $\mathrm{BW}$ relative to G1. ADG reached its peak between week 8 and 12 in G1, while the corresponding peak of G2 was between week 16 and 24 (Figure 1).

Overall mean ADG of G1 increased by $33 \%(\mathrm{P}<0.001)$ than that of G2 (0.96 vs. $0.72 \mathrm{~kg})$. This is because of feed conversion of G1 was less $(\mathrm{P}<0.01)$ than that of $\mathrm{G} 2$ by $1.7 \mathrm{~kg}$ DMI. This consequently shortened $(\mathrm{P}<0.001)$ fattening period of $\mathrm{G} 1$ by $23.4 \%$ than of G2 (Table 2).

\section{Carcass traits}

Carcass traits (dressing \%, boneless meat \%, rib components, L. dorsi area and expletive fat weight) of slaughtered Baladi bullocks showed non significant difference between G1 and G2 (Table 3). This most probably attributed to non significant difference in FBW of the two studied groups (Table 2).

\section{Economic indicators}

Total variable cost of $\mathrm{G} 2$ was less $(\mathrm{P}<0.02)$ than that of $\mathrm{G} 1$ by L.E 374 . However, no significant difference was observed in total outputs between the two studied groups. Benefit / cost ratio of G1 was higher $(\mathrm{P}<0.05)$ than that of $\mathrm{G} 2$ by $15 \%$. This is due to the low cost of producing $1 \mathrm{~kg}$ gained weight $(\mathrm{P}<0.02)$ in $\mathrm{G} 2$ than in $\mathrm{G} 1$ by $15.5 \%$. Feeding cost represented $94.8(\mathrm{P}<0.001)$ in $\mathrm{G} 1$ vs. $92.3 \%$ for $\mathrm{G} 2$, respectively out of the running cost (Table 4$)$. 


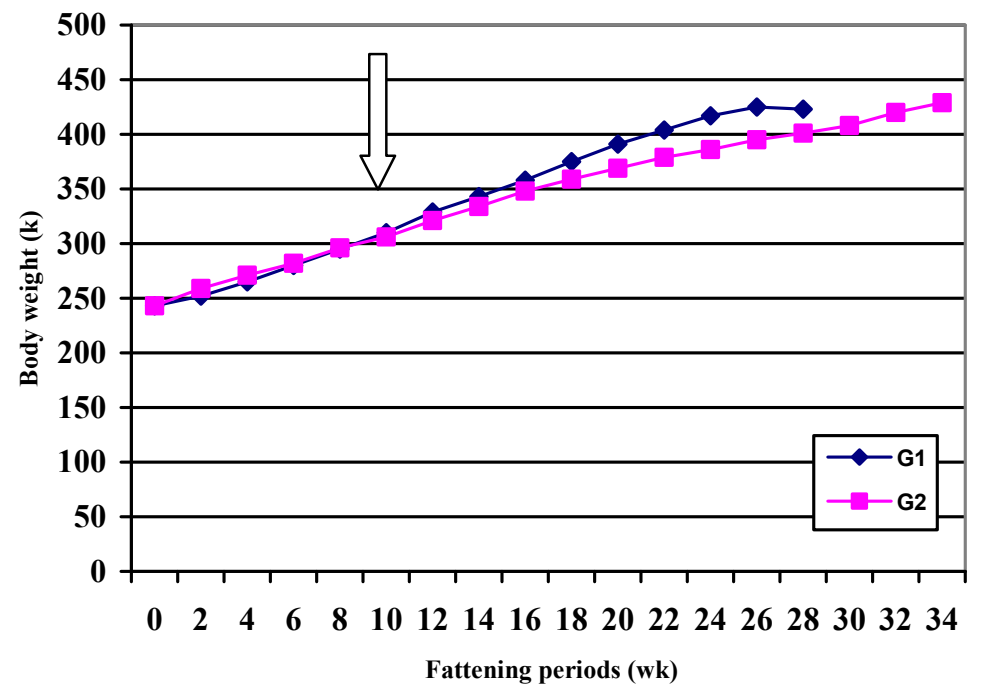

$\begin{array}{cccccc}\text { ADG (Kg) } & \text { Group } & \mathbf{0 - 8} & \mathbf{8 - 1 6} & \mathbf{1 6 - 2 4} & \mathbf{2 4 - 3 4} \\ & \text { G1 } & 0.873 & 1.040 & 1.000 & - \\ \text { G2 } & 0.817 & 0.858 & 1.000 & 0.723\end{array}$

Figure 1. Growth curve of Baladi bullocks fattened on $100 \%$ concentrate feed mixture (G1) and on $25 \%$ concentrate feed mixture plus $75 \%$ maize silage (G2)

Table 3. Carcass traits (LSM \pm S.E) of Baladi bullocks fattened on $100 \%$ concentrate feed mixture (G1) and on $25 \%$ concentrates mixture plus $75 \%$ maize silage (G2)

\begin{tabular}{|c|c|c|c|c|}
\hline Item & G1 & G2 & $\pm \mathbf{S . E}$ & P value \\
\hline Number of animals & 5 & 5 & & \\
\hline Hot carcass weight $(\mathrm{kg})$ & 247.9 & 240.0 & 3.9 & 0.2 \\
\hline Dressing percentage & 56.7 & 56.0 & 0.7 & 0.6 \\
\hline Boneless meat (\%) & 47.5 & 46.6 & 0.6 & 0.5 \\
\hline Eye muscle area $\left(\mathrm{cm}^{2}\right)$ & 71.1 & 70.0 & 4.5 & 0.9 \\
\hline \multicolumn{5}{|l|}{ Rib component $\left(9,10,11^{\text {th }}\right)$} \\
\hline Bone \% & 18.3 & 18.2 & 1.4 & 0.97 \\
\hline Fat $\%$ & 20.1 & 17.1 & 2.3 & 0.4 \\
\hline Lean \% & 61.5 & 64.6 & 1.5 & 0.2 \\
\hline Expletive fat weight (kg) & 26.2 & 23.3 & 3.4 & 0.5 \\
\hline
\end{tabular}


Table 4. Economic traits of fattening cycle (LSM \pm S.E) of Baladi bullocks fattened on $100 \%$ concentrate mixture (G1) and on $25 \%$ concentrate feed mixture plus $75 \%$ maize silage (G2)

\begin{tabular}{lcccc}
\multicolumn{1}{c}{ Item } & G1 & G2 & \pm S.E & P value \\
\hline $\begin{array}{l}\text { Number of animals } \\
\text { Variable cost (L.E) }\end{array}$ & 5 & 5 & & \\
$\quad$ Purchasing price/ animal & 3520.6 & 3581.5 & 60.5 & 0.5 \\
$\quad$ Feeding cost & 2016.9 & 1561.9 & 60.04 & 0.001 \\
$\quad$ Veterinary care cost & 30 & 30 & 0.0 & 0.0 \\
$\quad$ Labor cost & 80.7 & 100.8 & 2.7 & 0.001 \\
Total variable cost (L.E) & 5648.1 & 5274.2 & 86.14 & 0.02 \\
Outputs (L.E) & & & & \\
$\quad$ Selling price/animal & 6014.3 & 5896 & 54.05 & 0.2 \\
$\quad$ Manure price & 167.8 & 210.0 & 86.1 & 0.001 \\
$\quad$ Total Outputs (L.E) & 6182.1 & 6106 & 56 & 0.4 \\
Economic traits & & & & \\
$\quad$ Growth Margin (L.E) & 534 & 831.8 & 88.7 & 0.04 \\
$\quad$ Benefit /cost ratio & 1.1 & 1.16 & 0.4 & 0.05 \\
Cost of producing 1 kg gain (L.E) & 11 & 9.3 & 0.4 & 0.02 \\
\hline
\end{tabular}

\section{GENERAL DISCUSSION}

The obtained ADG of G1 $(0.96 \mathrm{~kg}$, Table 1$)$ is so close to that recorded by ElBedawy et al. (1996 \& 2004), Alsheikh et al. (2004) and Amal El-Asheeri (2008) $(0.9-1.02 \mathrm{~kg})$, while less than that reported by Sadek et al. $(1993,1.04 \mathrm{~kg})$. Results of Asker and Ragab (1958), Kamar et al. (1961) and Omar et al. (1993) on Baladi calves reported extremely lower ADG representing two-third $(0.6-0.72 \mathrm{~kg})$ of that obtained in the present study. This is may be due to the authors characterized ADG starting with younger ages and for longer periods than that applied in the present study. The higher ADG of G1 compared to G2 (Figure 1) is due to the lower feed intake and feed conversion of the later group (Table 2), which reflected negatively on fattening period required to reach the target final body weight. The no difference in carcass traits of G1 and G2 (Table 3) is most probably attributed to the insignificant difference between FBW of two groups.

The lower total cost / head in G2 compared to G1 (Table 4) by L.E 376 is mainly attributed to its lower feeding cost. The share of feeding $(92.3-94.8 \%)$ in the running cost is close to that reported by El-Asheeri (2008, $93 \%)$, however, less than that reported by Alsheikh et al. (2004, $86 \%)$. The increase in feeding cost is most probably attributed to the global increase in feed ingredients price in higher rates compared to the other in-puts components (labor and veterinary care).

In conclusion replacing concentrate feed mixture up to $75 \%$ with maize silage has a positive impact on benefit/cost ratio of Baladi bullocks under Egyptian condition.

\section{ACKNOWLEDGEMENT}

The author would like to thank Dr. M. A. M. Ibrahim, Associate Professor, Animal Husbandry, Faculty of Agriculture, Cairo University for his sincere help of 
analyzing data. Gratitude is also extended to the experimental station of Faculty of Agriculture, Cairo University for offering the animals and running cost of this experiment.

\section{REFERENCES}

Alsheikh, S. M., A. A. Younis, M. M. Mokhtar, 2004. Biological and economic assessment of fattening Egyptian native Baladi male calves in a newly reclaimed area. Egyptian Journal of Animal Production, 41, Suppl. Issue, Nov.: 85- 91.

A.O.A.C., 2000. Association of Official Analytical Chemists: Official Methods of Analysis $\left(13^{\text {th }}\right.$ Ed.) Washington, D. C., USA.

Asker, A. A. and M. T. Ragab, 1959. Fattening Egyptian steers in Tahreer province. Alex. J. Agric. Research, 7: 157-

El-Asheeri, Amal K., 2008. Profitability of Baladi calf feedlots under different fattening systems. Egyptian Journal of Animal Production,45 (Suppl. Issue), 5767.

E1- Bedawy, T. M., M. A. I. Salem and E. A. Badr, 1996. Effect of dietary fat on growth performance and carcass characteristics of finishing bulls. Egyptian Journal of Animal Production, 33(Supplement issue): 103-111.

El- Bedawy, T. M., M. A. I. Salem and A. S. Sami, 2004. Calcium soaps in low or high roughage rations: 2- Effect on growth performance, carcass characteristics and meat quality of growing finishing Baladi bulls. Egyptian Journal of Animal Production, 41(2): 61-71.

Galal, E., A. A. Younis, K. G. Attia and A. B. Awad, 1973. The performance of Egyptian native Baladi male calves during fattening. Egyptian Journal of Animal Production, 2: 71

Gozzi, G., F. Gottardo, and I. Andrighetto, 2005. The use of coarse maize silage as a dietary source of roughage for finishing limousine bulls: effects on growth performance, feeding behaviour and meat quality. Animal science 80: 111-118.

Kamar, G. A. R., A. L. Badreldin and H. Z. Abd El-Hady, 1961. Factors affecting gain in fattening Egyptian steers on clover. Journal of Animal Production, U. A. R., 19: 32.

Karadjole. I., Rako, A. and Mikulec, K. 1983. Compensatory growth and quality of meat in young fattening cattle. CAB Stocarstvo. 37: 65-69 Abstract.

Mader, L. T., J. M. Dahlquist and L. D. Schmidt, 1991. Roughage sources in beef cattle finishing diets J Anim. Sci. 69: 462-471.

Nigm A. A., A. Mostageer, M. A. Morsy, M. A. I. Salem and F. Pirchner, 1984. Feed efficiency of beef production of Baladi and its crossbreds with central European cattle. Z. Tierzuchtg. Zuchtgsbiol. 101: 173-181.

NRC, 1996. Nutrient Requirements of beef cattle. National Research Council, National Academy Press, Washington, D. C. Seventh Revised Edition: Update 2000. http://www.nap.edu/catalog/9791.html

Omar, S.S., M.A. Houria and G. A. Baraghite, 1993. Studies on growth performance of male buffalo and bovine calves under commercial fattening farms in Menofiya province. Egyptian Journal of Animal Production, 30 (2):117-128.

Rossi, E. J. and S.C. Loerch, 2001. Proportion of corn silage in diets of feedlot steers fed to achieve stepwise increases in growth. J. Anim. Sci. 79:1402-1408. 
Sadek, R. R., M. A. Morsy, A. A. Nigm, M. A. M. Ibrahim and A. M. Sabry, 1993. The effect of grading up Baladi cattle with Friesian on meat production performance. Egyptian Journal of Animal Production, 30 (2): 143-160.

Sami, A. S., C. Augustini and F. J. Schwarz, 2004. Effects of feeding intensity and time on feed on performance, carcass characteristics and meat quality of Simmental bulls. Meat Science. 67(2): 195-201.

SAS (2001) SAS institute Inc., Cary, NC. USA.

Sewell, B.H. and H. N. Wheaton, 1993. Corn silage for beef cattle.. http://extension.missouri.edu/explore/agguides/ansci/g02061.htm

Wand, C. and P. McEwen, 2003. Corn Silage in Beef Production http://www.omafra.gov.on.ca/english/livestock/speakers/silage/silage.htm

Young, W. A. and G. R. Kauffman, 1978. Evaluation of Beef from Steers Fed Grain, Corn Silage or Haylage-Corn Silage Diets. J Anim. Sci. 46:41-47. 
الآداء البيولوجي والاقتصادي لمزارع تسمين العجول البقرى تحت نظامين للتسمين آمال كمال العشيرى، أحمد سعد سامى، محمد على رضوان قسم الإنتاج الحيوانسى ، كلية النزاعة، جامعة القاهزة، الجبيزة، مصر

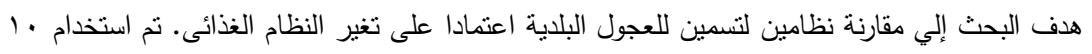

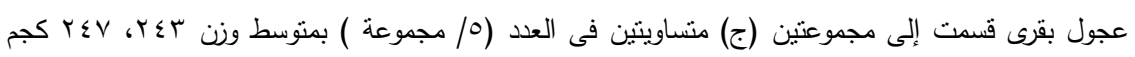

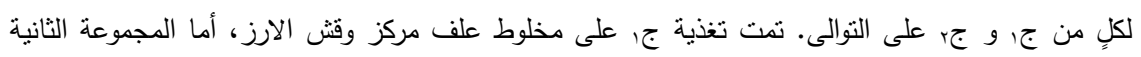

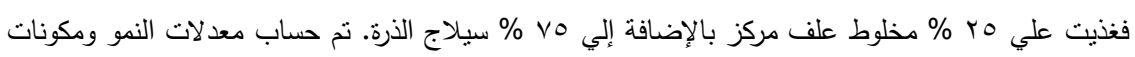

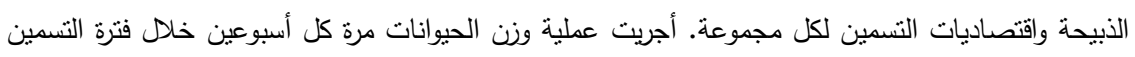

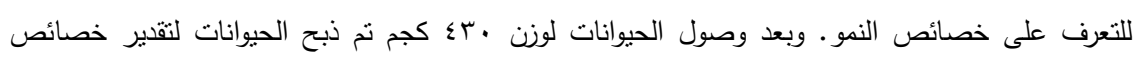

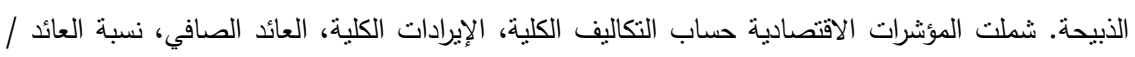

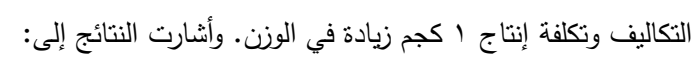

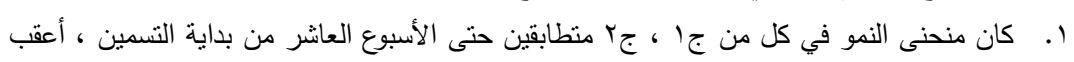

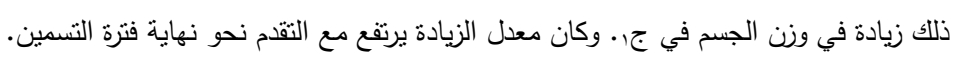

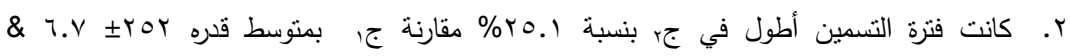

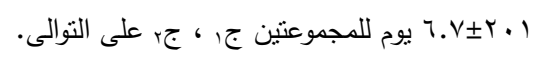

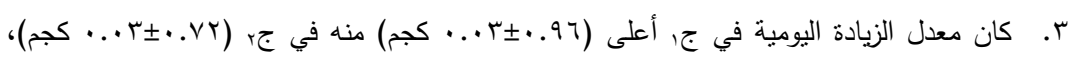

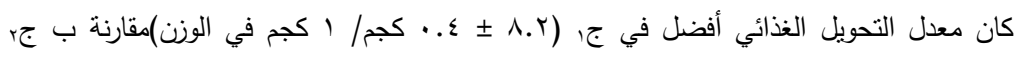

(كج)

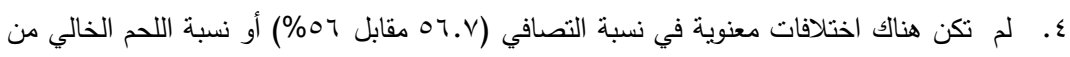

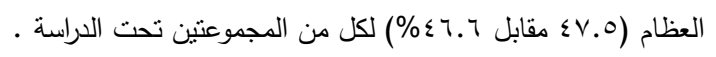

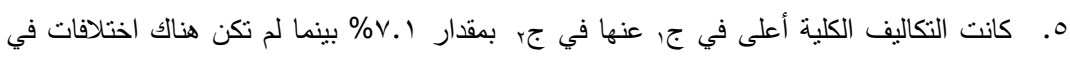

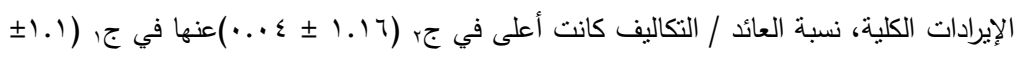

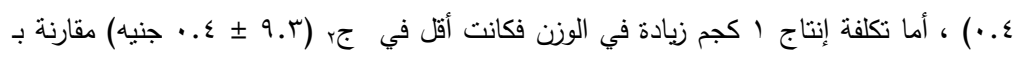

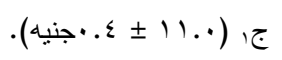

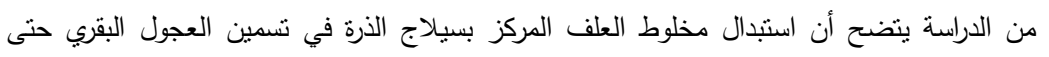

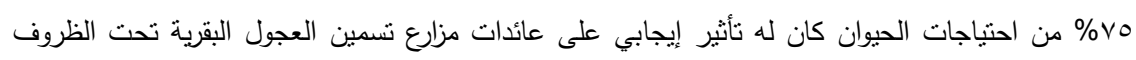

